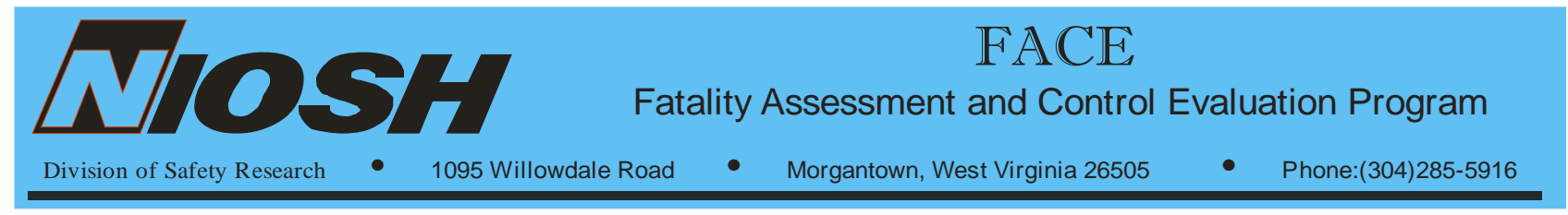

FACE Report Number 2012-02

January 12, 2015

\title{
Hispanic worker falls from residential roof - North Carolina
}

\section{SUMMARY}

On April 19, 2012, a 37-year-old Hispanic male laborer fell approximately 13.5 feet from a residential roof to a concrete driveway; he died immediately from his injuries. The laborer was working with a crew of eight Hispanic workers for a construction subcontractor replacing shingles on a roof accessed by a ladder. At the time of the incident, five workers were on the roof, including the laborer who was out of sight of his coworkers working on the garage side of the home. When the incident occurred, the co-workers heard the laborer hit the ground, rushed to his aid, and called 911. Emergency Medical Services were dispatched to the incident and the laborer was pronounced dead at the scene.

\section{CONTRIBUTING FACTORS}

Key contributing factors identified in this investigation include:

- 13-foot plus fall distance and concrete surface

- 10/12 roof pitch

- 25-foot working length of fall arrest system lifeline

- Fall arrest system lanyard connection point

- Fall arrest system anchorage method

- Worker's level of experience / lack of training

\section{RECOMMENDATIONS}

NIOSH investigators concluded that, to help prevent similar occurrences, employers should:

- Develop, implement, and enforce a comprehensive, safety program

- Ensure that all employees working at heights are provided with fall prevention training that complies with OSHA standards, in a language and at a literacy level that they can comprehend

- Ensure that all employees are provided with properly assembled and maintained fall protection systems when exposed to fall hazards

\section{Fatality Assessment and Control Evaluation (FACE) Program}

The National Institute for Occupational Safety and Health (NIOSH), an institute within the Centers for Disease Control and Prevention (CDC), is the federal agency responsible for conducting research and making recommendations for the prevention of work-related injury and illness. In 1982, NIOSH initiated the Fatality Assessment and Control Evaluation (FACE) Program. FACE examines the circumstances of targeted causes of traumatic occupational fatalities so that safety professionals, researchers, employers, trainers, and workers can learn from these incidents. The primary goal of these investigations is for NIOSH to make recommendations to prevent similar occurrences. These NIOSH investigations are intended to reduce or prevent occupational deaths and are completely separate from the rulemaking, enforcement and inspection activities of any other federal or state agency. Under the FACE program, NIOSH investigators interview persons with knowledge of the incident and review available records to develop a description of the conditions and circumstances leading to the deaths in order to provide a context for the agency's recommendations. The NIOSH summary of these conditions and circumstances in its reports is not intended as a legal statement of facts. This summary, as well as the conclusions and recommendations made by NIOSH, should not be used for the purpose of litigation or the adjudication of any claim. For further information, visit the program website at www.cdc.gov/niosh/face/ or call toll free at 1-800-CDC-INFO (1-800-232-4636). 
- Assign a competent person to inspect the worksite before work begins to identify fall hazards, determine the appropriate fall prevention systems for workers, and ensure that personal fall arrest systems (PFAS) are installed properly

Additionally, general contractors:

- General contractors should ensure through contract language that all subcontractors have a comprehensive safety program

\section{INTRODUCTION}

At 9:15 am, on April 19, 2012, a 37-year-old construction laborer was fatally injured when he fell 13.5 feet from a residential roof to a concrete driveway. On April 23, 2012, the North Carolina Department of Labor/Occupational Safety and Health Division (NCDOL/OSH) notified the National Institute for Occupational Safety and Health (NIOSH), Division of Safety Research (DSR) of the incident. On July 24, 2012, a Health Scientist and a Safety and Occupational Health Specialist conducted an investigation of the fatality and reviewed circumstances of the incident with the investigating NCDOL Safety Compliance Officer. Photographs of the incident site and witness statements taken by the NCDOL Safety Compliance Officer obtained through a translator were reviewed. The roofing job had been completed by the time of the NIOSH investigation. The medical examiner report was reviewed. The medical report contained the official cause of death provided by the emergency response personnel who had pronounced the laborer dead on site.

\section{EMPLOYER}

The general contractor, a residential roofing contractor, employed eight workers, and had been in business for one year. The general contractor hired three to four subcontractors to complete residential roofing projects throughout North Carolina. These projects involved removing and replacing shingles and disposing of debris. The projects were typically completed over a one- to two-day period. The laborer was employed by one of the subcontractors as a construction laborer. The subcontractor had been in business for at least 2 years, and employed eight Hispanic employees to complete roofing jobs at residential construction sites. The subcontractor and his employees spoke Spanish and very limited English.

\section{TRAINING AND EXPERIENCE}

The 37-year-old Hispanic laborer was originally from Honduras and his first language was Spanish. He had worked for one day for the subcontractor as a construction laborer removing and replacing shingles, and cleaning up debris. At the time of the incident, he was wearing a hard hat and a personal fall arrest system (PFAS) which included a full body harness, lanyard, rope grab, roof anchor, and 50-foot lifeline rigged to reach 25 feet laterally.

\section{WRITTEN SAFETY PROGRAMS and TRAINING}

At the time of the incident, according to NCDOL/OSH, the subcontractor did not have a comprehensive written safety program and the laborer had not received any formal safety training. The general contractor had a written safety program including safety rules, contractor 


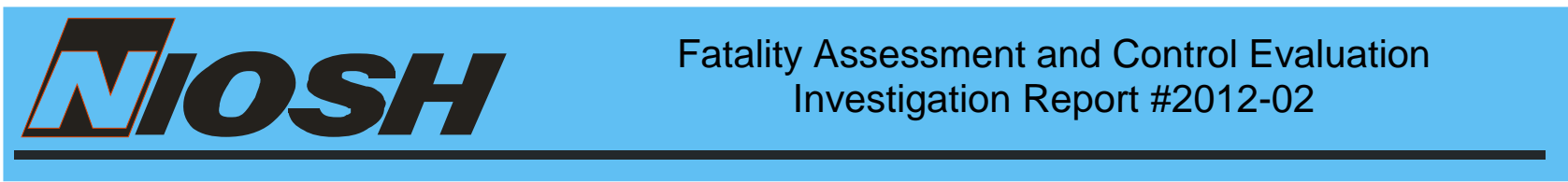

safety program, subcontractor responsibilities, statement of understanding for roofing subcontractors, subcontractor agreement, fall protection program, and a jobsite safety checklist. The general contractor had not initiated the fall protection training program at the time of the incident.

INCIIDENT SCENE

The incident occurred at a private residence in a suburb. The building was one and a half stories with a complex gable roof including a main hip ridgeline, four minor gable ridgelines to the front side of the structure, and one gable to rear of the structure. The gable to the far right was the garage roof where the laborer was working. The roof heights varied from 13 to 27 feet and the roof pitches were between 8/12 and 10/12 (Photo 1). The laborer was working on the garage roof that measured 23.1 feet to the peak and 13.5 feet to the eave (Photo 2). The roofing project required approximately 30 squares of shingles. The residence was located on a mainly flat plot, with a manicured lawn with shrubberies around the perimeter. A concrete driveway lead up to the two-car garage and concrete pathways lead to the front doorway.

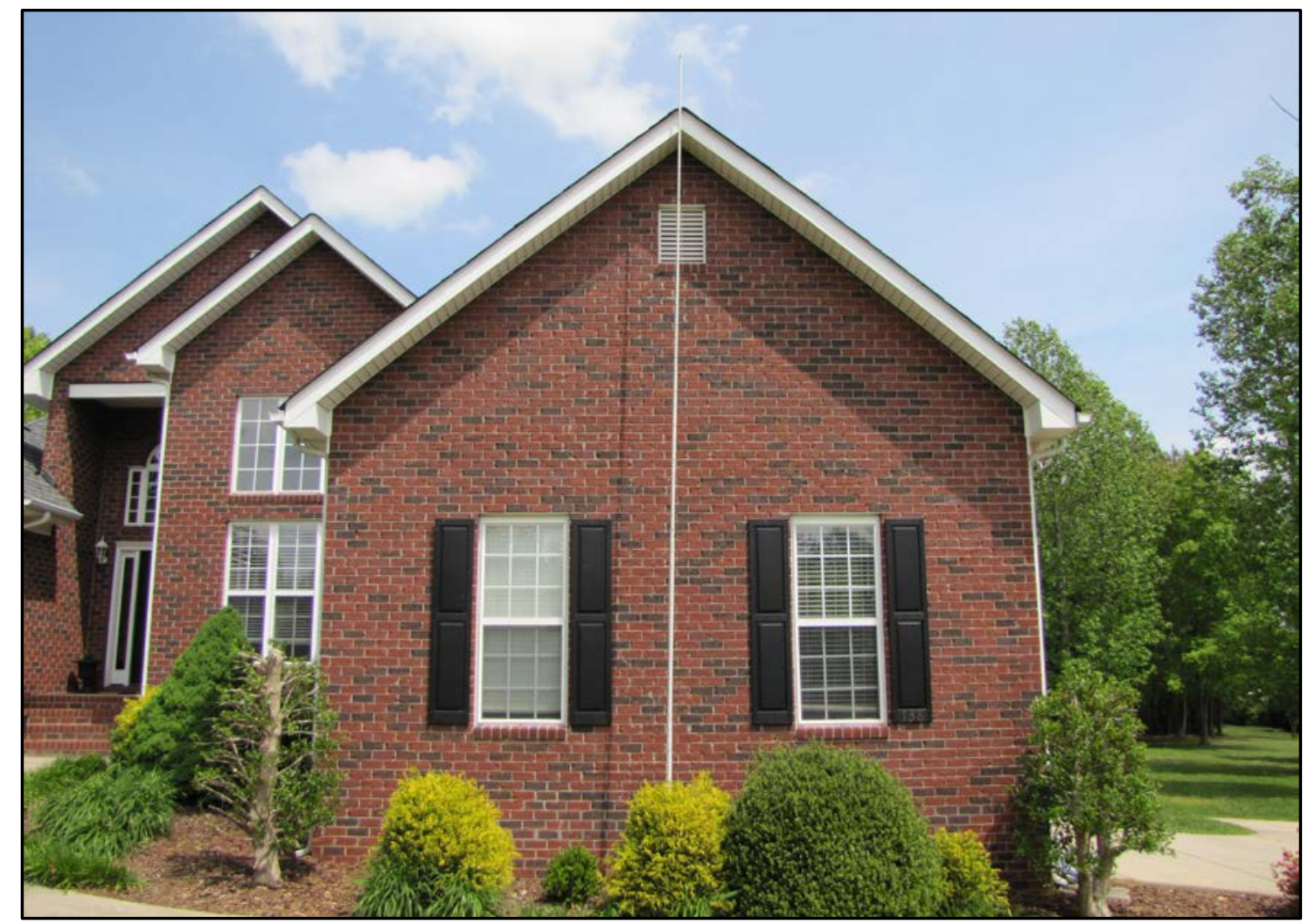

Photo 1. Roof pitch of the garage was determined to be 10/12 (Photo courtesy of NCDOL/OSH) 

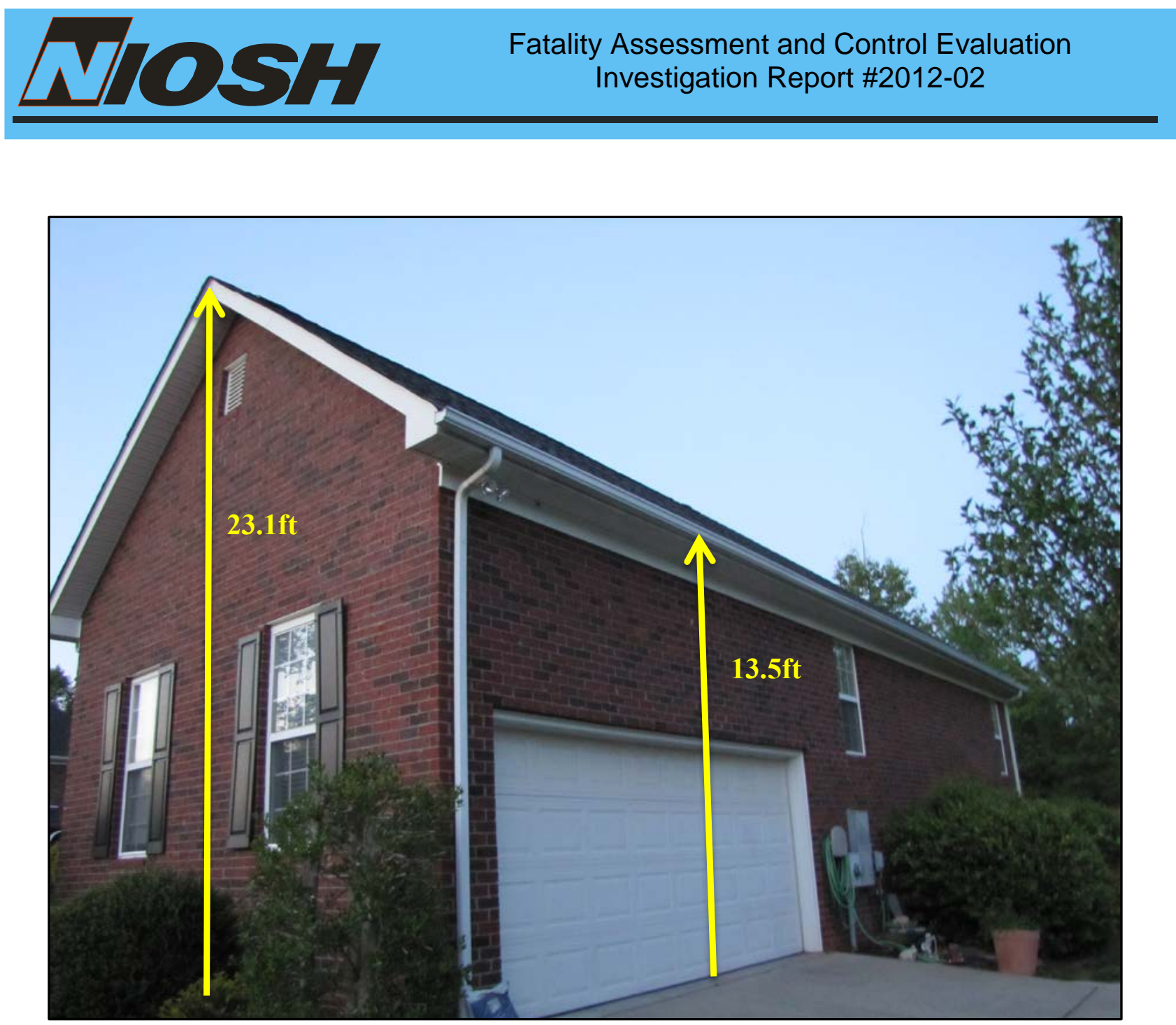

Photo 2. Garage where laborer was working (Photo courtesy of NCDOL/OSH)

\section{WEATHER}

The weather at the time of the incident was a high of 60 degrees, $65 \%$ humidity, and 6 mph wind speed. The weather is not believed to have been a factor in this incident ${ }^{1}$.

\section{INVESTIGATION}

On April 19, 2012, a 37-year-old Hispanic construction laborer began working his first day on a residential roof replacement project. He and seven other employees were assigned by a subcontractor to a two-day project to remove, replace, and dispose of roofing shingles for a residence that had received hail damage. The homeowner had hired a general contractor to replace the old shingles. Based on the photos at the time of the incident the laborer was wearing a full body harness with lanyard and rope grab attached to a 50-foot lifeline.

He was working alone on the garage roof at the time of the incident. The garage roof had a 10/12 pitch roof with a height of 23.1 feet at the peak and 13.5 feet at the eave (Photos $1 \& 2$ ). The other employees were working on other portions of the roof and on the ground. It is believed the laborer lost his footing then slipped and slid down the roof, falling more than 13.5 feet to the 


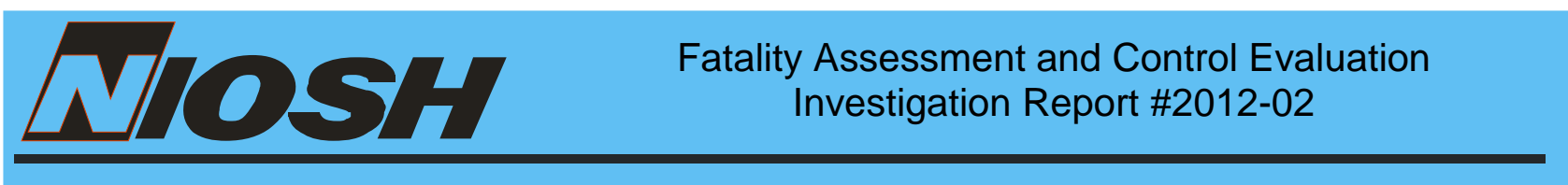

concrete driveway. He was not in view of the other workers on the roof at the time of the incident who heard the impact when he landed on the driveway. The employee on the ground responded to the laborer then called for help and asked another employee to call 911.

Based on photos retrieved from the scene, the anchor for the laborer's PFAS had pulled from the peak (Photo 3). Further investigation of the anchor suggests that it had been installed laterally along the ridge of the roof with two or three nails of unknown size. The lifeline was found coiled near the laborer's hand. The rope grab was attached to the right leg webbing of his harness rather than the D-ring anchor, and the energy-absorbing lanyard was attached to the roof anchor. The harness, lanyard, rope grab, and connectors appeared to be in good condition and were within the 5-year recommended service life. There were damaged fibers at the 25-foot mark on the 50-foot lifeline (Photo 4).

\section{CONTRIBUTING FACTORS}

Occupational injuries and fatalities are often the result of one or more contributing factors or key events in a larger sequence of events that ultimately result in the injury or fatality. NIOSH investigators identified the following unrecognized hazards as key contributing factors in this incident:

- 13-foot plus fall distance and concrete surface

- 10/12 roof pitch

- 25-foot working length of fall arrest system lifeline

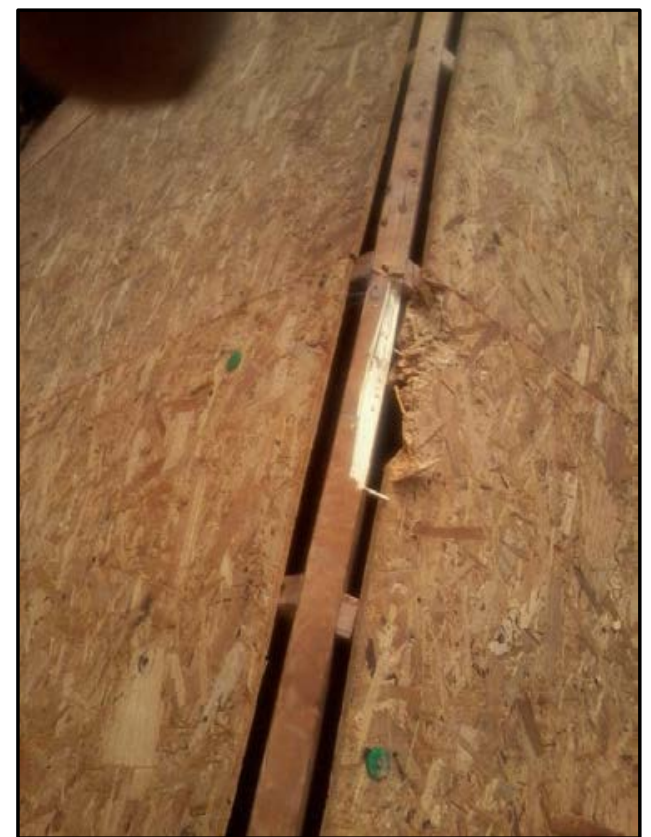

Photo 3. PFAS anchor location after incident (Photo courtesy of $\mathrm{NCDOL/OSH)}$

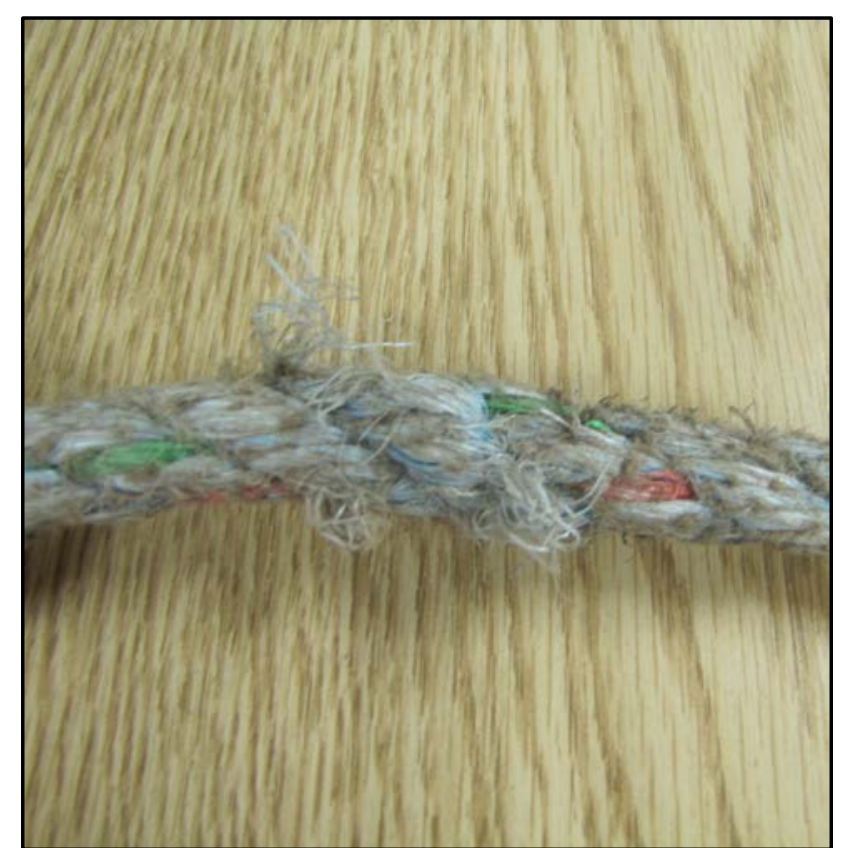

Photo 4. Damaged fibers in laborer's 50-foot lifeline (Photo courtesy of NCDOL/OSH) 
- Fall arrest system lanyard connection point

- Fall arrest system anchorage method

- Worker level of experience / lack of training

CAUSE OF DEATH

Fall from height, blunt trauma to the head according to the NCDOL report.

\section{RECOMIMENDATIONS / DISCUSSION}

Recommendation \#1: Employers should develop, implement, and enforce a comprehensive, safety program.

Discussion: According to 29 CFR 1926.20(b)(1) and (2) $)^{2}$, employers are responsible for developing safety programs for the construction site that are designed to prevent worker injury. The safety and health program should include at a minimum: an explanation of the worker's rights to protection in the workplace, safe work practices employees are expected to adhere to, specific safety protection for all tasks performed, frequent and regular inspections, ways to identify and avoid hazards, and who employees should contact when safety and health issues or questions arise, in a language spoken and understood by all employees.

According to 29 CFR 1926.21(b)(2) ${ }^{3}$, employers are required to instruct each employee in the recognition and avoidance of unsafe conditions and the regulations applicable to the work environment using a language and literacy level that all employees can comprehend. The program should also require that site-specific training be conducted and documented. Hazard recognition training should be based on an evaluation of the tasks employees will perform for all potential hazards. The training should also include specific instructions that employees should not risk physical harm to accomplish tasks. OSHA regulations require employers to train employees to recognize and avoid unsafe conditions that may be present in their work environments, and to provide training on the regulations applicable to their work. Documentation of this training should include: who provided the training and their qualifications, date of training, the content of the training, employees who were trained, and any assessments of employees' comprehension of the training. The safety program shall include frequent and regular inspections of the jobsites, materials, and equipment, conducted by a competent person designated by the employer.

In this case, the safety program and training topics should have included fall hazards, fall protection systems, hazard recognition, and the avoidance of unsafe conditions. Although the general contractor had developed a general safety program, the fall protection program had not been implemented and formal inspections of the work site had not occurred at the time of the incident. The subcontractor had not developed any type of safety program.

Recommendation \#2: Employers should ensure that all employees working at heights are provided with fall prevention training that complies with applicable OSHA fall prevention standards, in a language and at a literacy level that they employees can comprehend. The 
program should include safe work practices, hazard awareness and identification, avoidance of fall hazards, and the correct assembly, installation and use of the personal fall arrest system.

According to 29 CFR 1926.503(a)(1) $)^{4}$ employers are required to provide construction workers working at heights 6 feet or more above a lower level with fall protection and training in fall protection by a competent person that is qualified in the following fall protection elements:

- The nature of fall hazards in the work area;

- $\quad$ The correct procedures for erecting, maintaining, disassembling, and inspecting the fall protection systems to be used;

- The use and operation of guardrail systems, personal fall arrest systems, safety net systems, warning line systems, safety monitoring systems, controlled access zones, and other protection to be used;

- The role of each employee in the safety monitoring system when this system is used;

- The limitations on the use of mechanical equipment during the performance of roofing work on low-sloped roofs;

- The correct procedures for the handling and storage of equipment and materials and the erection of overhead protection;

- The role of employees in fall protection plans, and:

- The standards contained in subpart M.

In this case, fall protection equipment was provided by the employer but no training was provided to the employees on: fall hazard recognition, procedures for erecting, maintaining, disassembling, and inspecting the fall protection systems, or limitations of the equipment. The laborer was from Honduras and his first language was Spanish. The immediate supervisor, the subcontractor from North Carolina, spoke little English and most of his crew members spoke Spanish and understood little English. Offering training in Spanish could have ensured that the crew members were aware of the fall hazards posed by the job site and the need to correctly assemble and use the fall protection systems. The laborer coiled the excess slack of the lifeline instead of using the rope grab to reduce the lifeline slack. It was his first day on the job, and his employer had not trained him to recognize fall hazards or methods of protection, so he may not have understood the proper installation, use, and limitations of the PFAS he was wearing.

\section{Recommendation \#3: Employers should ensure that all employees are provided with properly assembled and maintained fall protection systems when exposed to fall hazards.}

Discussion: Employers in residential construction, including subcontractors, are required to provide employees with a fall protection system (e.g. guardrail systems, safety net systems, or personal fall arrest systems) when employees are walking/working on a surface, horizontal and vertical, with an unprotected side or edge which is 6 feet or more above a lower level. A Personal Fall Arrest System (PFAS) is designed to stop a worker's fall before they strike a lower level 
(Photo 5 \& Photo 6). According to OSHA regulations the general contractor who has control of the work site has a responsibility to ensure workers on the site are in compliance with OSHA standards found in 29 CFR $1926.501^{\frac{5}{}}$. This fall protection system must be in accordance with the fall protection criteria, requirements for fall protection systems, criteria, and practices that are found in 29 CFR $1926.502^{6}$.

According to 29 CFR 1926.502(d)(15) ${ }^{6}$ the anchorage points used for attachment of personal fall arrest equipment shall be independent of any anchorage being used to support or suspend platforms and capable of supporting at least 5,000 pounds $(22.2 \mathrm{kN})$ per employee attached, or shall be designed, installed, and used as part of a complete personal fall arrest system which maintains a safety factor of at least two under the supervision of a qualified person. The anchor for the PFAS used in this incident is believed to have been installed horizontally along the ridgeline of the roof, secured with 3 roofing nails into the sheathing (Photo 3). To meet the 5,000 pounds per employee support requirement, the manufacturer recommends installing the anchor over the ridgeline, with a minimum of 10 to12, 3-inch, $16 \mathrm{~d}$ nails through the holes, into the truss (Photo 7).

According to 29 CFR 1926.502(d)(16)(iii) ${ }^{6}$ the PFAS should be rigged such that an employee can neither free fall more than 6 feet $(1.8 \mathrm{~m})$, or contact any lower level. There was only one anchor installed across the ridgeline, the manufacturer recommends anchors be installed a minimum of 5 feet from the ridge ends and a maximum of every 8 feet along the peak (Diagram 1). The laborer's lifeline was rigged at 25 feet with a 6-foot lanyard, which gave him 31 feet of rope and the PFAS system was anchored approximately 29 feet from the ground. He was also working laterally away from the anchor point allowing the swing effect in the event of a fall (Diagram 2 \& Diagram 3). In order to minimize the swing effect workers should work directly below the anchor and not extend their work area beyond 30 degrees from the anchor point ${ }^{7}$. 

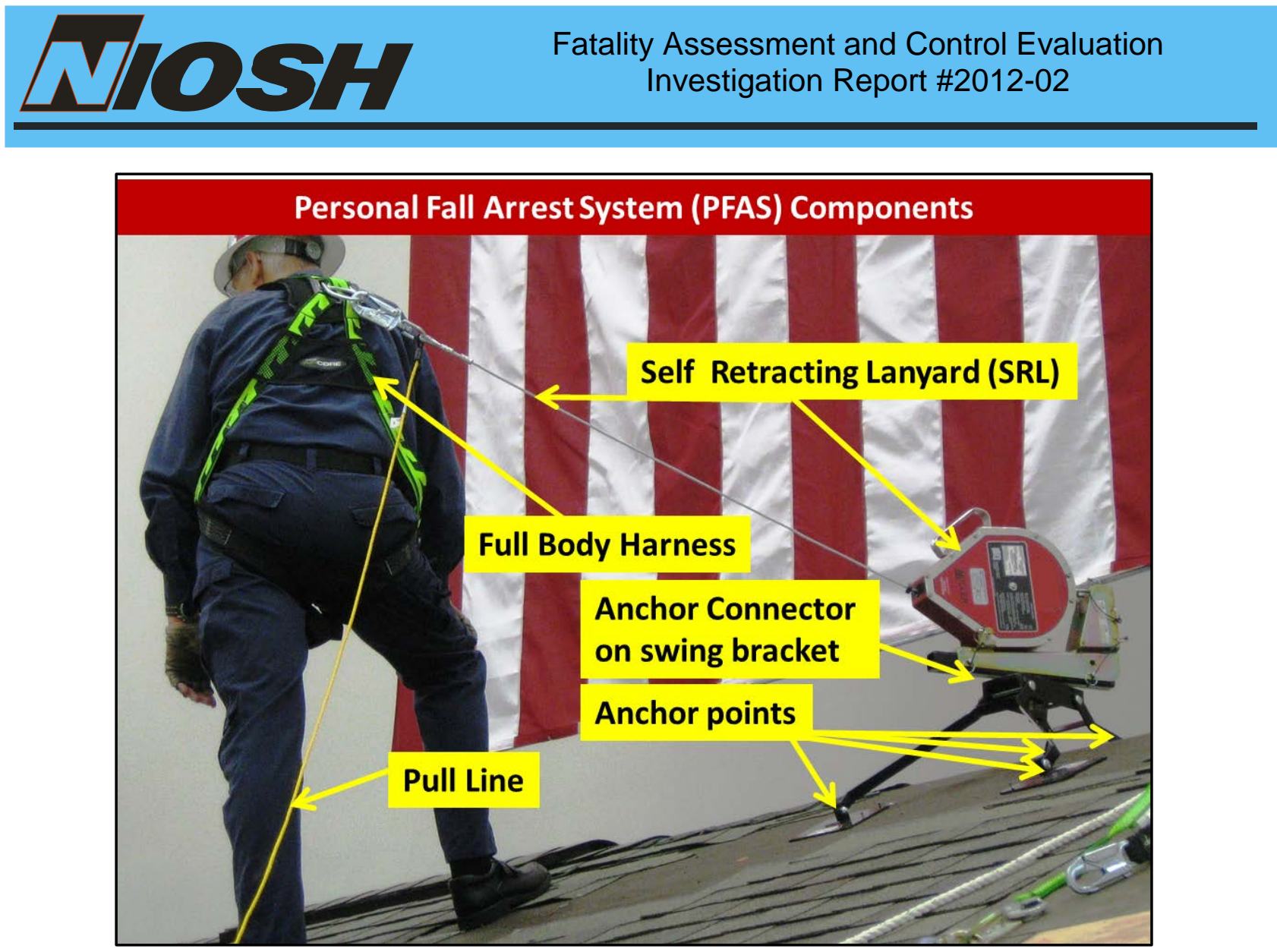

Photo 5. Proper components of a PFAS (Photos courtesy of John Eckel, Honeywell)

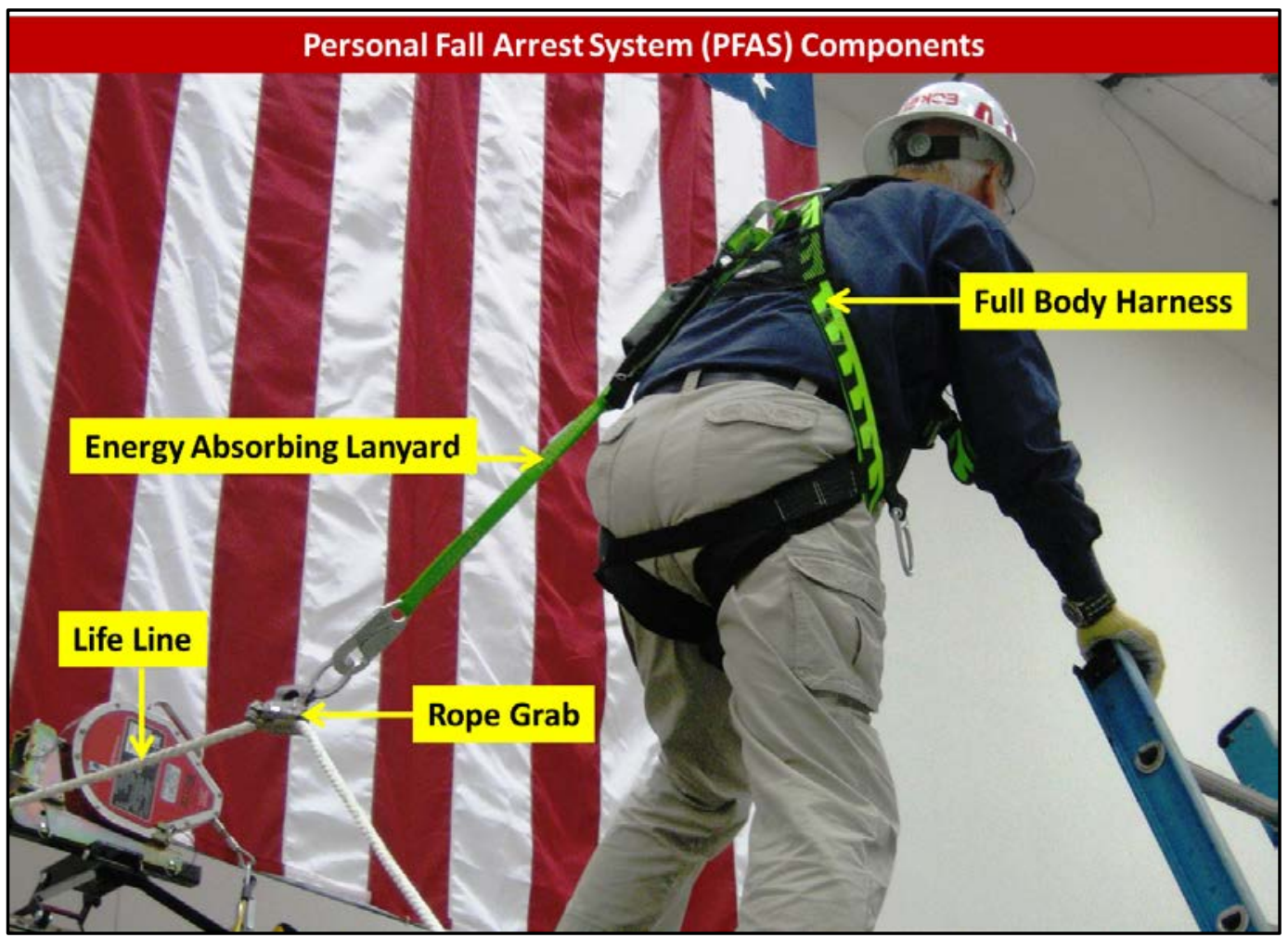

Photo 6. Proper components of a PFAS (Photos courtesy of John Eckel, Honeywell) 


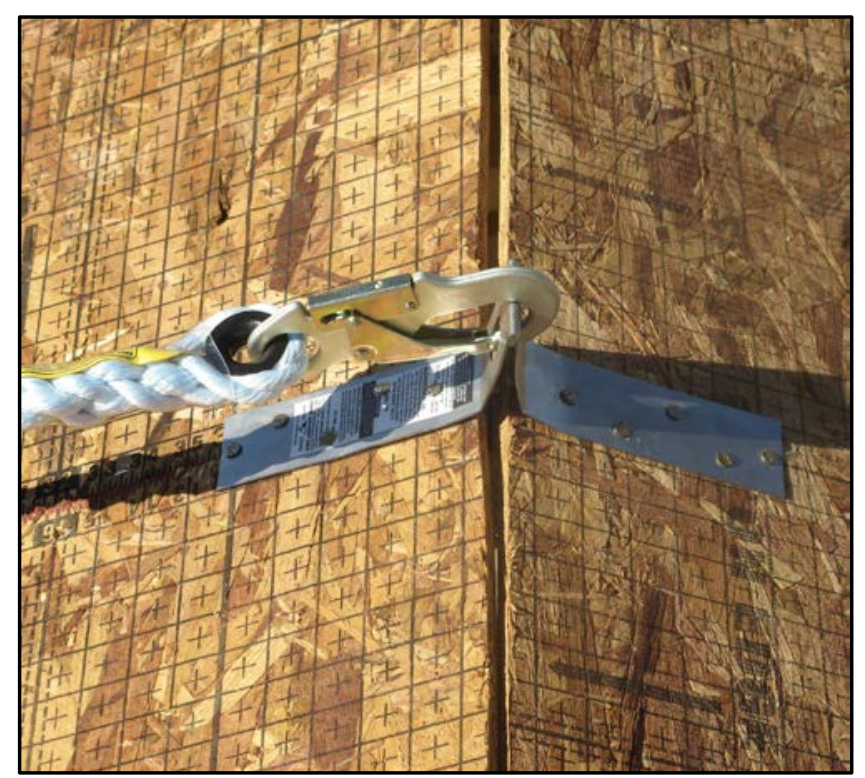

Photo 7. Proper installation of PFAS anchor (Photo courtesy of NAHB) ${ }^{7}$

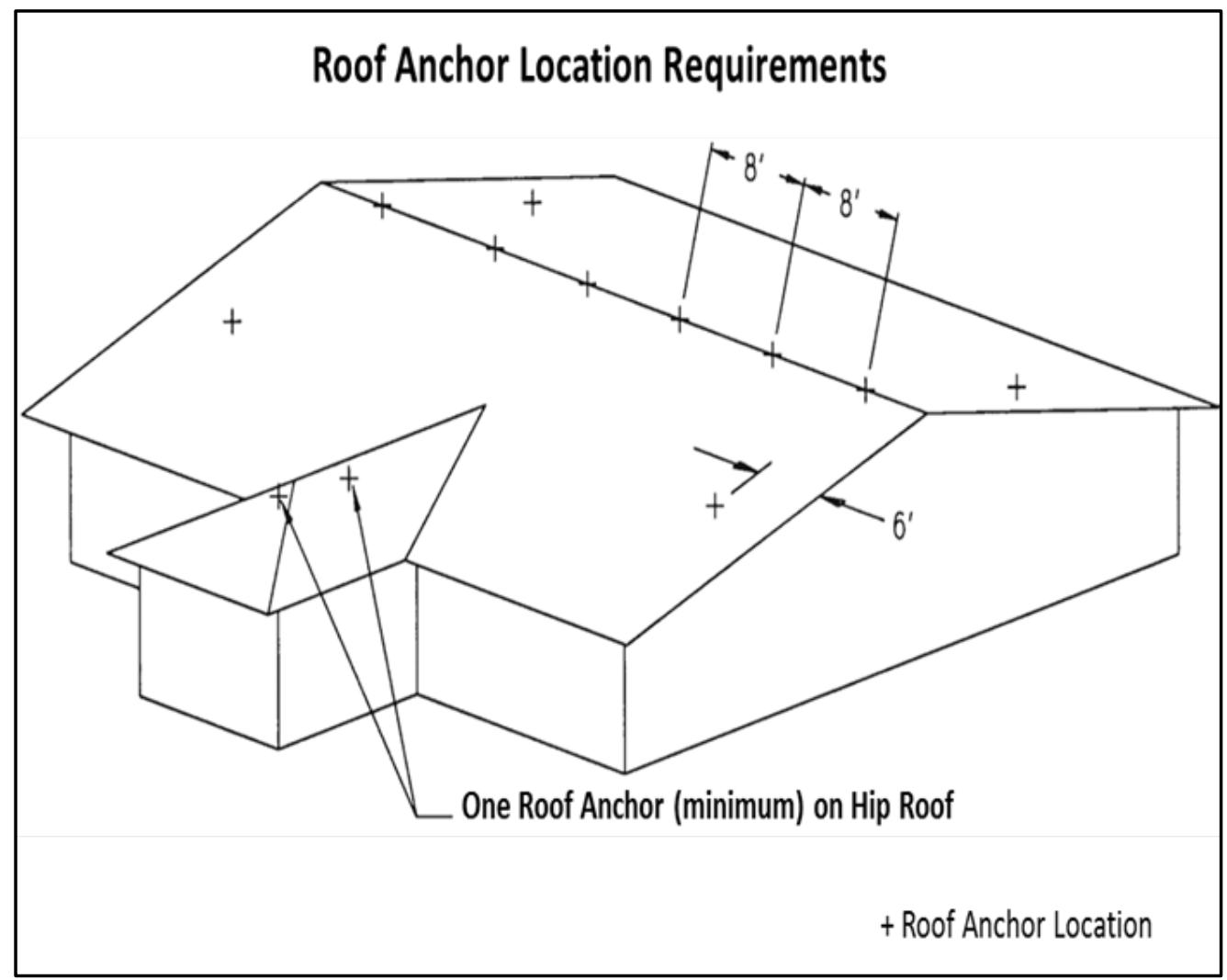

Diagram 1. Example of typical roof bracket installation on residential roof (Diagram courtesy of DBI-SALA/Capital Safety) ${ }^{7}$ 


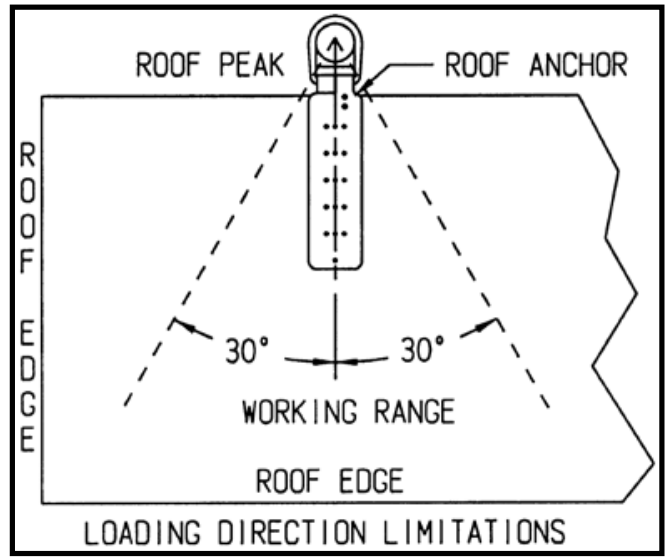

Diagram 2. Working range for PFAS anchor point (Diagram courtesy of DBISALA/Capital Safety) ${ }^{\underline{7}}$

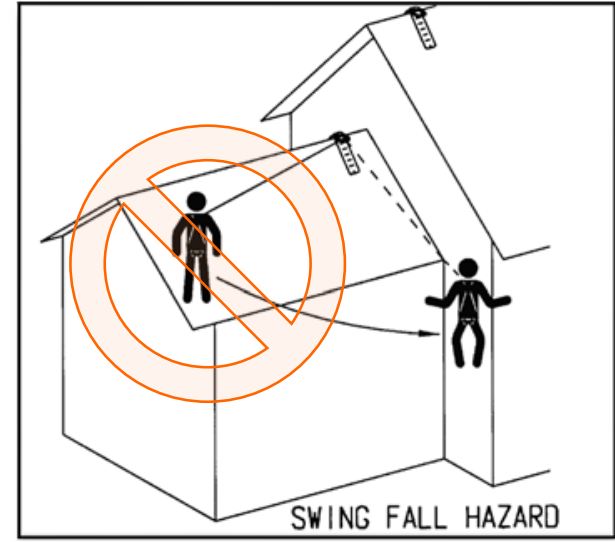

Diagram 3. Swing hazard for PFAS anchor point (Diagram courtesy of DBISALA/Capital Safety) ${ }^{7}$

According to 29 CFR 1926.502(d)(21) ${ }^{6}$ personal fall arrest systems shall be inspected prior to each use for wear, damage and other deterioration, and defective components shall be removed from service. In this case, the 50-foot lifeline was damaged at the 25 -foot mark and should have been removed from service.

According to the PFAS manufacturer, the attachment point of the body harness to the lanyard/lifeline system shall be located in the center of the wearer's back near the shoulder. The laborer had attached the lifeline with rope grab to the right leg webbing on his harness and the energy-absorbing lanyard to the roof anchor instead of the dorsal D-ring (Photo 5 \& Photo 6). He coiled the excess slack of the lifeline instead of using the rope grab to reduce the lanyard slack. It was his first day on the job and he had not been trained to recognize fall hazards or taught methods of fall protection, so he may not have understood the proper installation, use, and limitations of the PFAS was wearing.

Recommendation \#4: Employers should assign a competent person to inspect the worksite before work begins to identify fall hazards, determine the appropriate fall prevention systems for workers, and ensure the PFAS is installed properly.

Discussion: According to 29 CFR $1926.32^{8}$, a competent person is one who can identify existing and predictable hazards in the surroundings or working conditions that are unsanitary, hazardous, or dangerous to workers, and is authorized to take prompt corrective measures to eliminate them. In this case, a competent person may have recognized that the PFAS was not being used according to the manufacturers' recommendations and could have, at a minimum, made the necessary changes to install the appropriate anchorage points, attach the lanyard properly to the safety harness, and inform the laborer of the proper way to reduce excess slack from the lanyard. 


\section{Recommendation \#5: General contractors should ensure through contract language that subcontractors have a comprehensive safety program.}

General contractors should ensure through contract language that all subcontractors have implemented comprehensive safety programs that appropriately address the tasks their workers perform. A multilingual safety program and training may have allowed the workers to better understand the safest way to perform the roofing job.

\section{ADDITIONAL INFORMATION}

NIOSH, OSHA, and CPWR have teamed up to prevent falls from height in construction. Information related to this campaign can be found at: http://stopconstructionfalls.com/

\section{DISCLAIMER}

Mention of any company or product does not constitute endorsement by the National Institute for Occupational Safety and Health (NIOSH). In addition, citations to Web sites external to NIOSH do not constitute NIOSH endorsement of the sponsoring organization or their programs or products. Furthermore, NIOSH is not responsible for the content of those web pages.

\section{REFERENCES}

1. Weather Underground http://www.wunderground.com/history/airport/KJQF/2013/5/16/DailyHistory.html Accessed: December 2014

2. Code of Federal Regulations [2014].29 CFR 1926.20(b)(1)(2). General Safety and Health Provisions. Washington, DC: U.S. Government Printing Office, Office of the Federal Register.

3. Code of Federal Regulations [2014]. 29 CFR 1926.21(b)(2). Safety Training and Education. Washington, DC: U.S. Government Printing Office, Office of the Federal Register.

4. Code of Federal Regulations [2014].29 CFR 1926.503. Fall Protection: Training requirements. Washington DC: U.S. Government Printing Office, Office of the Federal Register.

5. Code of Federal Regulations [2014].29 CFR 1926.501. Fall Protection: Duty to have fall protection. Washington, DC: U.S. Government Printing Office, Office of the Federal Register.

6. Code of Federal Regulations [2014].29 CFR. 1926.502. Fall Protection: Fall protection systems criteria and practices. Washington DC: U.S. Government Printing Office, Office of the Federal Register. 


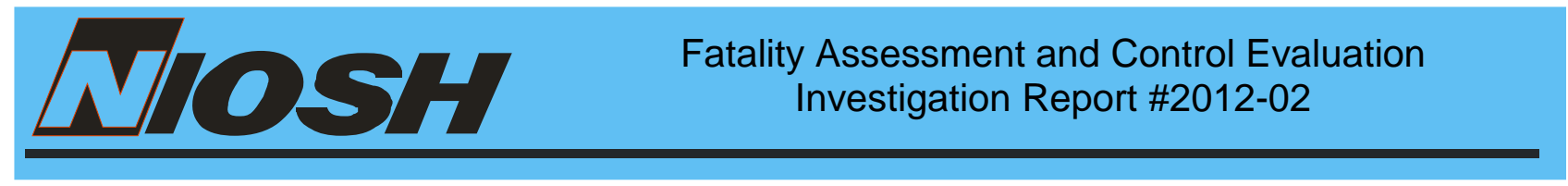

7. Fall Protection Training, Section 4: Roofing Operations. National Association of Home Builders Research Center, 400 Prince George’s Blvd., Upper Marlboro, MD 20774. http://www.toolbase.org/Best-Practices/Job-Site-Safety/fall-protection-training Accessed: December 2014

8. Code of Federal Regulations [2014].29 CFR 1926.32.Definitions: competent person. Washington, DC: U.S. Government Printing Office, Office of the Federal Register.

9. Fall prevention fact sheet [2012] Washington, DC: U.S. Department of Health and Human Services, Public Health Service, Centers for Disease Control and Prevention, National Institute for Occupational Safety and Health, DHHS (NIOSH) Publication No. 2012-142, 2012 Apr; :1-4 http://www.cdc.gov/niosh/docs/2012-142/pdfs/2012-142.pdf Accessed: December 2014

\section{INVESTIGATOR INFORMATION}

This investigation was conducted by Jennifer E. Lincoln, Health Scientist, and Virginia Lutz, Safety and Occupational Health Specialist, Fatality Investigations Team, Surveillance and Field Investigation Branch, Division of Safety Research.

\section{ACKNOWLEDGEMEMENT}

The NIOSH FACE Program and the Safety and Occupational Health Specialists would like to acknowledge the Compliance Officer and staff of the North Carolina Department of Labor, Occupational Safety and Health Division, Mark Fullen and Brandon Tacaks from the West Virginia University Safety and Health Extension, John Eckel from Honeywell, Robert Matuga from the National Association of Home Builders Research Center, and Jeff Hallback from DBISALA/Capital Safety for providing assistance and information for this investigation. 